
org/10.1590/S0102-053620170416

\title{
Productivity and quality of melon cultivated in a protected environment under different soil managements
}

\section{Carlos Eduardo P Lima ${ }^{1}$; Mariana R Fontenelle ${ }^{1}$; Gabriela R Ligoski² ${ }^{2}$ Nuno R Madeira ${ }^{1}$; Valter R Oliveira ${ }^{1}$; Jadir B Pinheiro'; Rubens S Gondim³; Mirtes F Lima ${ }^{1}$}

1Embrapa Hortaliças, Brasília-DF, Brasil; carlos.pacheco-lima@embrapa.br; mariana.fontelle@embrapa.br; nuno.madeira@embrapa.br; valter.oliveira@embrapa.br; jadir.pinheiro@embrapa.br; mirtes.lima@embrapa.br; ${ }^{2}$ Universidade Católica de Brasília (UCB), Brasília-DF, Brasil; ligoskigabriela@gmail.com; ${ }^{3}$ Embrapa Agroindústria Tropical, Fortaleza-CE, Brasil; rubens.gondim@embrapa.br

\begin{abstract}
The need to adapt agricultural crops to climate change and to develop more sustainable cultivation systems has been a major challenge for agriculture. In this study the effects of soil conservation practices were evaluated on production aspects of melon (Cucumis melo), cultivar BRS Araguaia, cultivated in a greenhouse under soil and climatic conditions of the Brazilian Cerrado. The adopted experimental design was of randomized blocks with three treatments (soil managements) and six replicates. We evaluated the following soil management systems: no-tillage (PD), minimum tillage (CM) and conventional tillage (PC) in two cycles. Increases in commercial productivity and average number of marketable fruits were observed for PD (61.5 and 61.2 t/ha; 56,000 and 44,300 fruits/ha in the first and second cycles, respectively) and CM (59.7 and 57.5 t/ha; 55,700 and 42,400 fruits/ha in the first and second cycles, respectively). No effects of management systems on fruit quality were observed. PD and $\mathrm{CM}$ were effective in increasing the melon production under evaluated conditions.
\end{abstract}

Keywords: Cucumis melo, no-tillage, minimum tillage, conventional tillage, greenhouse.

\section{RESUMO}

Produtividade e qualidade de melão cultivado em ambiente protegido com diferentes manejos de solos

A necessidade de adaptação de cultivos agrícolas às mudanças climáticas, aliada à necessidade de desenvolvimento de cultivos mais sustentáveis constitui um grande desafio para a agricultura. $\mathrm{O}$ presente trabalho teve como objetivo avaliar os efeitos de sistemas de manejo de solo conservacionistas sobre aspectos produtivos de melão amarelo (Cucumis melo), cultivar BRS Araguaia, cultivado em ambiente protegido em condições edafoclimáticas do Cerrado brasileiro. $\mathrm{O}$ experimento foi conduzido em delineamento de blocos ao acaso, com três tratamentos (manejos de solo) e seis repetições. Foram avaliados os seguintes sistemas de manejo de solo: plantio direto na palha (PD), cultivo mínimo (CM) e plantio convencional (PC), em dois ciclos culturais. Foram observados incrementos na produtividade e no número médio de frutos produzidos quando do uso do PD (61,5 e 61,2 t/ha no primeiro e segundo ciclo, respectivamente) e do CM (59,7 e 57,5 t/ha no primeiro e segundo ciclo, respectivamente). Nenhum efeito dos sistemas de manejo sobre a qualidade dos frutos foi observado. O PD e o CM foram eficientes em aumentar a produção do melão amarelo nas condições avaliadas.

Palavras-chave: Cucumis melo, plantio direto na palha, cultivo mínimo, preparo convencional, cultivo protegido.

Received on November 29, 2016; accepted on Mai 4, 2017

$\mathrm{M}$ elon (Cucumis melo) is originated from the warm valleys of Iran and from the Northwest of India (Filgueira, 2008), that is the reason why the crop is best adapted to warm regions, with accentuated dry periods. Nowadays, the largest producing region in Brazil is the Northeast. The northeastern melon market is not only restricted to the national market, considering that a part of the production is destined to the exportation due to the high quality of fruits. The demand for the product, however, is not restricted to the region and the service to local markets may allow the production reach other Brazilian regions.

Climate projections for the end of the $21^{\text {st }}$ century indicate a clear trend towards the increase of the average temperature of the planet, as demonstrated by the IPCC (2014). In Brazil, Hamada et al. (2012) reported a strong trend towards an increase in average air temperature for all the Brazilian regions, with major climatic anomalies that are expected for the Central-West region. This fact highlights a possible need, in the
Central West region, of agricultural practice management adapted to such temperature conditions, favoring species adapted to warm conditions. Limiting factors, especially in springsummer, should be the high rainfall rates commonly observed and also the possibility of concentration, at the same time, of extreme rainfall events according to Hamada et al. (2012). Due to that, productivity gains, using agricultural production in a protected environment, becomes a very good opportunity. The possibility of obtaining 
high productivity of melon grown in a greenhouse was demonstrated by Gualberto et al. (2001).

In relation to the sustainability of agricultural production systems, special attention has been given to soil quality. In this sense, management systems with low tillage system such as no-tillage or minimum tillage have been used to obtain productivity gains, and to maintain soil quality. Special attention is recommended, since literature on this matter is scarce, to adoption of conservation practices in the greenhouse and the effects on productivity aspects, mainly for melon crop. Previous experiments showed good responses of melon grown under open field conditons when mulching, either artificial or composed of vegetable residues, was maintained during the crop cycle (Silva et al., 2005; Câmara et al., 2007; Morais et al., 2008, 2010; Lourenção et al., 2013). In this work the hypothesis tested was if melon cultivation in a greenhouse can be benefited either by straw left on the soil surface, or by the incorporation of straw into soil, with positive effects on productive components, capable of supplying specific market niches and adding value to the final product, key factors to compensate high costs of protected cultivation.

Thus, this research aimed to evaluate the productivity and postharvest characteristics of melon, cultivar BRS Araguaia, grown in a greenhouse under three different soil management systems: no tillage (PD), minimum tillage (CM) and conventional tillage (PC) under soil and climatic conditions of the Brazilian Cerrado and two distinct periods of the year.

\section{MATERIAL AND METHODS}

The experiment was carried out in the experimental field of Embrapa Hortaliças, in Brasília, Brazil (1556'S, $48^{\circ} 08^{\prime} \mathrm{W}$, altitude $\left.997.6 \mathrm{~m}\right)$, from October 2013 to November 2014. The cultivar BRS Araguaia, a "yellow" melon hybrid (Cucumis melo), developed at Embrapa and Emater was used in the assay. The soil was classified as typic dystrophic Red Latosol, very clayey texture. The soil chemical attributes are shown in Table 1. According to Köppen, the climate is Aw (tropical savanna with rainfall concentration in summer).

The experiment was carried out in a protected environment, in a greenhouse with $7 \mathrm{~m}$ width $\mathrm{x} 50 \mathrm{~m}$ length, covered with low-density polyethylene film, 150 micron thickness and anti-aphid screen. The experimental layout was a randomized block design, with three treatments (soil management) and six replicates. The treatments were: notillage (T1), conventional tillage (T2); and minimum tillage (T3), spacing of $0.30 \mathrm{~m}$ between plants and 0.8 $\mathrm{m}$ between rows. Two plant lines composed each experimental plot, being the useful area of $5.6 \mathrm{~m}^{2}$ (7 m length $\mathrm{x}$ $0.8 \mathrm{~m}$ width). Seedlings were grown in styrofoam trays. Transplanting (DAT) was carried out at 15 days after sowing in previously opened pits. The plants were tutored using nylon threads, with two fruits per plant. Tutoring of plants started at 18 days after transplanting.

Two experimental cycles, during two different cultivation periods, were performed. The first cycle was between October 2013 and January 2014, representing a period characterized by high temperature and high rainfall occurrence (average temperature of $22.55^{\circ} \mathrm{C}$ and total precipitation of 1284.8 $\mathrm{mm})$. The second cycle was from the end of July 2014 to November 2014, a period characterized by high temperatures and very low rainfall occurrence (average temperature of $22.61^{\circ} \mathrm{C}$ and total precipitation of $480.8 \mathrm{~mm}$ ).

Millet (Pennisetum glaucum) was used as cover crop (mulch) for straw formation. Seeds were hand sown, with high density, in the whole greenhouse. The average development cycle of the millet was 60 days. At the end of the cycle, the cover crop and straw were managed using a crusher-disintegrator followed by application of the disiccant glyphosate at sprouting, and application of the disiccant Paraquat a week before melon planting. In the treatment $\mathrm{T} 1$, the straw was maintained on the soil surface; In T2, it was taken from the experimental plots and incorporated subsurface with semi-opened grid in T3.

No-tillage management (PD) was related to straw formation and to open pits for planting, with minimum soil disturbance. Conventional tillage management (PC) was carried out with plowing (one) and harrowing (twice) and opening of pits for planting. For minimum tillage (CM), one subsuperficial harrowing was performed, with a levelling semi-opened grid so that the straw could be incorporated up to $10 \mathrm{~cm}$ deep.

Spray applications were performed to control pests and diseases in both planting cycles. In the first cycle, at 17 DAT, a solution of a fungicide $(2 \mathrm{~g} / \mathrm{L})$ containing the active ingredients pyraclostrobin and metiram at concentrations 50 and 550 $\mathrm{g} / \mathrm{kg}$ was applied covering the whole area, to control the powdery mildew; at 28 DAT the aphid and whitefly were controlled with a spay insecticide $(0.44$ $\mathrm{g} / \mathrm{L})$ containing the active ingredients thiamethoxam and cypermethrin at 750 and $30 \mathrm{~g} / \mathrm{kg}$ on the whole area. In the second cycle, at 1 DAT and 8 DAT, a solution of the fungicides $(0.75 \mathrm{~g} / \mathrm{L})$ thiophanate-methyl + chlorothalonil metiran was applied on the whole area, at concentrations of 200 and $500 \mathrm{~g} / \mathrm{kg}$, respectively.

The nutrition of the melon plants was performed, exclusively, through fertigation. A dripping irrigation system was used and, the doses of fertilizers were measured with a dispenser (Venturini type). Nutrient was supplied according to the need observed for the cultivar, in experiments previously conducted at Embrapa Hortaliças. At the end of the cycle, an amount equivalent to $190 \mathrm{~kg} /$ ha of $\mathrm{N}, 120 \mathrm{~kg} / \mathrm{ha}$ of $\mathrm{P}_{2} \mathrm{O}_{5}$ and $170 \mathrm{~kg} /$ ha of $\mathrm{K}_{2} \mathrm{O}$ was supplied.

In the first cultivation cycle, the harvests were done on January $9^{\text {th }}, 16^{\text {th }}$ and $22^{\text {nd }}, 2014$. In the second cycle, the harvests were carried out on October $30^{\text {th }}$, November $11^{\text {th }}$ and $19^{\text {th }}, 2014$. After each harvest, the following agronomic variables were evaluated: marketable fruits productivity, average weight per fruit, number of marketable fruits, fruit diameter, pulp thickness, pulp texture and soluble solid content ( ${ }^{\circ}$ Brix).

The evaluation of agronomic attributes followed protocols commonly employed in the sector of Protected Cultivation of Embrapa Hortaliças. 
The mass of marketable fruits, used to determine the marketable fruits productivity and average weight per fruit, was determined with the aid of a scale with a maximum capacity of $60 \mathrm{~kg}$.

In order to determine other postharvest traits, five marketable fruits were randomly obtained. The fruits were cut in halves using a knife. In one of the halves, the longitudinal length of the fruit and pulp thickness were determined, using a graduated ruler. The pulp firmness was evaluated with the aid of a penetrometer. For this last analysis, seven random readings were obtained throughout the fruit pulp. Soluble solid content was determined from the juice of the fruit pulp, using a refractometer Atago Digital PR-1. The procedures were carried out similarly to that used by Terceiro Neto et al. (2013).

The results were submitted to the analysis of variance using the statistical program SISVAR. When ANOVA was significant, the averages were compared by the Scott-Knott test at a $5 \%$ significance level.

\section{RESULTS AND DISCUSSION}

\section{Productivity and components}

Analysis of variance showed that, at a $5 \%$ significance level, there were significant statistical differences, in both productive cycles, for the following attributes: marketable fruits productivity and average number of marketable fruits per treatment (Table 2).

Significantly higher productivity of marketable fruits was observed for PD (Table 2). The average marketable fruits productivity for the system was 61.49 $\mathrm{t} /$ ha. The intermediate productivity was for CM (59.71 t/ha). Significantly low productivity was observed for PC (44.18 t/ha). Similar results were found for the second cultivation cycle (Table 2), although no differences between the average of commercial productivities provided by PD and CM were noticed. In the second cycle, however, the highest commercial productivities were observed for PD, and CM, 61.17 and 57.54 t/ha, respectively. Productivities found for all treatments were quite superior, reaching almost three times the Brazilian average productivity in 2012, which was 22.96 t/ha (Agrianual, 2013). The values obtained were similar to those obtained by Gualberto et al. (2001) for net melon grown in a greenhouse in the State of São Paulo.

Braga et al. (2010) found, in an experiment conducted in open field under Northeastern semi-arid climatic conditions and six different kinds of mulches, synthetic and natural, higher commercial productivities compared to the treatment without mulches. These productivities were still similar to those found in the present study for treatments which used PD. Although both experiments were performed in different productive systems, the results show a tendency to maintain higher productivities when mulch is used (Silva et al., 2005; Câmara et al., 2007; Morais et al., 2008, 2010; Lourenção et al., 2013). The increase in productivity in relation to the use of mulch has been attributed to the reduction of water evaporation, to the lower thermal

Table 1. Chemical attributes of typic dystrophic Red Latosol previously to experiment implementation. Brasília, Embrapa Hortaliças, 2016.

\begin{tabular}{|c|c|c|c|c|c|c|c|c|c|}
\hline \multirow{2}{*}{$\begin{array}{l}\text { Management } \\
\text { system }\end{array}$} & $\mathrm{pH}\left(\mathrm{H}_{2} \mathrm{O}\right)$ & $\mathbf{P}$ & $\mathbf{K}$ & $\mathrm{Na}$ & $\mathbf{C a}$ & Mg & $\mathbf{A l}$ & $\mathrm{H}+\mathrm{Al}$ & \multirow{2}{*}{$\begin{array}{l}\text { MOS } \\
(\mathrm{g} / \mathrm{kg})\end{array}$} \\
\hline & \multicolumn{3}{|c|}{$\left(\mathrm{mg} / \mathrm{dm}^{3}\right)$} & \multicolumn{5}{|c|}{$\left(\mathrm{cmol}_{\mathrm{c}} / \mathrm{dm}^{3}\right)$} & \\
\hline & \multicolumn{9}{|c|}{ First cycle } \\
\hline & \multicolumn{9}{|c|}{$0-10 \mathrm{~cm}$} \\
\hline $\mathrm{CM}$ & $6.8 \pm 0.6$ & $125.0 \pm 55.8$ & $338.2 \pm 140.0$ & $8.0 \pm 1.3$ & $10.2 \pm 2.1$ & $3.3 \pm 0.3$ & 0.0 & $1.4 \pm 1.0$ & $45.3 \pm 3.2$ \\
\hline $\mathrm{PC}$ & $6.9 \pm 0.4$ & $125.7 \pm 31.3$ & $332.7 \pm 186.3$ & $8.3 \pm 0.5$ & $11.0 \pm 2.3$ & $2.8 \pm 0.2$ & 0.0 & $1.2 \pm 1.2$ & $44.0 \pm 2.9$ \\
\hline \multirow[t]{2}{*}{$\mathrm{PD}$} & $7.2 \pm 0.5$ & $117.9 \pm 14.3$ & $336.7 \pm 187.3$ & $9.0 \pm 1.3$ & $12.0 \pm 1.7$ & $3.1 \pm 0.5$ & 0.0 & $0.7 \pm 1.0$ & $43.6 \pm 3.5$ \\
\hline & \multicolumn{9}{|c|}{$10-30 \mathrm{~cm}$} \\
\hline $\mathrm{CM}$ & $6.6 \pm 0.6$ & $107.7 \pm 39.9$ & $341.0 \pm 135.9$ & $8.7 \pm 0.8$ & $10.4 \pm 2.2$ & $3.1 \pm 0.5$ & 0.0 & $1.9 \pm 1.2$ & $41.3 \pm 6.2$ \\
\hline $\mathrm{PC}$ & $6.8 \pm 0.5$ & $121.6 \pm 27.3$ & $369.5 \pm 149.1$ & $8.3 \pm 0.5$ & $10.0 \pm 3.1$ & $3.2 \pm 0.3$ & 0.0 & $1.7 \pm 1.1$ & $44.9 \pm 2.7$ \\
\hline \multirow[t]{3}{*}{$\mathrm{PD}$} & $7.0 \pm 0.5$ & $145.7 \pm 70.0$ & $458.3 \pm 73.6$ & $9.2 \pm 1.5$ & $11.3 \pm 2.6$ & $3.2 \pm 0.2$ & 0.0 & $1.1 \pm 1.1$ & $41.9 \pm 4.1$ \\
\hline & \multicolumn{9}{|c|}{ Second cycle } \\
\hline & \multicolumn{9}{|c|}{$0-10 \mathrm{~cm}$} \\
\hline $\mathrm{CM}$ & $6.9 \pm 0.5$ & $130.3 \pm 40.9$ & $565.0 \pm 149.8$ & $14.2 \pm 1.2$ & $10.6 \pm 1.9$ & $4.1 \pm 0.5$ & 0.0 & $0.7 \pm 0.6$ & $39.7 \pm 1.3$ \\
\hline $\mathrm{PC}$ & $6.7 \pm 0.4$ & $77.0 \pm 14.8$ & $346.5 \pm 106.9$ & $13.5 \pm 2.1$ & $11.4 \pm 1.5$ & $3.6 \pm 0.3$ & 0.0 & $1.0 \pm 0.5$ & $39.4 \pm 1.0$ \\
\hline \multirow[t]{2}{*}{$\mathrm{PD}$} & $6.9 \pm 0.5$ & $107.4 \pm 26.4$ & $571.7 \pm 96.8$ & $14.7 \pm 0.8$ & $12.6 \pm 2.0$ & $3.6 \pm 0.3$ & 0.0 & $0.7 \pm 0.6$ & $42.7 \pm 1.4$ \\
\hline & \multicolumn{9}{|c|}{$10-30 \mathrm{~cm}$} \\
\hline $\mathrm{CM}$ & $6.8 \pm 0.6$ & $108.7 \pm 27.8$ & $623.3 \pm 243.5$ & $13.3 \pm 1.6$ & $11.4 \pm 2.4$ & $3.9 \pm 0.4$ & 0.0 & $0.8 \pm 0.8$ & $35.0 \pm 1.4$ \\
\hline $\mathrm{PC}$ & $6.6 \pm 0.4$ & $99.2 \pm 33.1$ & $331.7 \pm 129.6$ & $14.7 \pm 1.8$ & $10.7 \pm 2.0$ & $3.5 \pm 0.3$ & 0.0 & $1.0 \pm 0.5$ & $32.4 \pm 1.4$ \\
\hline PD & $6.8 \pm 0.5$ & $91.2 \pm 35.6$ & $427.5 \pm 149.2$ & $13.8 \pm 1.6$ & $11.3 \pm 2.6$ & $3.6 \pm 0.2$ & 0.0 & $0.7 \pm 0.6$ & $36.9 \pm 2.1$ \\
\hline
\end{tabular}

$\mathrm{CM}=$ minimum soil tillage system; $\mathrm{PC}=$ conventional soil tillage system; $\mathrm{PD}=$ no soil tillage system. 
amplitude, to no contact of the fruit with naked soil, greater availability and lower nutrient leaching, to less occurrence of weeds, among others (Brandenberger \& Wiedenfeld, 1997; Araújo et al., 2003). It is interesting to highlight that the use of vegetation cover resulting from the systematization and long-term conduction of no-tillage system (PD) shows even less environmental impact and provides, with an effective crop rotation, maintenance of the aggregation (Assis \& Lanças, 2005, 2010). In addition, it increases the amount (stocks) of organic matter and its fractions (Figueiredo et al., 2007; Carneiro et al., 2008), increases nutrient contents (Neto et al., 2010), among others, improving soil quality. In general, productivities obtained for all treatments are superior to those found in other studies (Araújo et al., 2003; Araújo Neto et al., 2003; Silva et al., 2005; Nunes et al., 2005; Santos et al., 2011; Lourenção et al., 2013).

In the first cycle, the following average weights per fruit were observed: $920 \mathrm{~g}$ in PD, $890 \mathrm{~g}$ in PC, $870 \mathrm{~g}$ in CM. In the second cycle, these values were: $839 \mathrm{~g}$ in PD; $870 \mathrm{~g}$ in $\mathrm{PC}$ and $888 \mathrm{~g}$ in CM. These fruit weight values are lower than those found in other papers, especially for hybrids of "yellow" melon produced in the Northeastern semi-arid region (Araújo Neto et al., 2003; Araújo et al., 2003; Nunes et al., 2005; Santos et al., 2011). The low values for average weight per fruit observed in the present study may be due to the higher plant density used $(0.8 \mathrm{~m}$ between rows and $0.3 \mathrm{~m}$ between plants). In the study reported by Terceiro Neto et al. (2013), the spacing used for growing melon in open field conditions in Northeastern semi-arid region was of $2.0 \mathrm{~m}$ between rows and $0.5 \mathrm{~m}$ between plants.

Average weight per fruit similar to those found in this research were also observed by Gualberto et al. (2001) and Frizzone et al. (2005) for net melon grown in a greenhouse in the State of São Paulo. Gualberto et al. (2001) verified that the increase of spacing decreased the productivity of net melon in a protected environment. Additionally, the average weight per fruit in their work, for the greatest spacing used between lines $(70 \mathrm{~cm})$ was the closest to the fruit average weight observed in this research. Significant differences among treatments were observed for the average number of marketable fruits in the two production cycles. PD and CM systems resulted in higher number of fruits, whereas PC provided lower values for this parameter. In the first cycle, PD and CM management systems resulted in average fruit number of 37.5 and 37.3 , respectively. These values are statistically superior to the average number of produced fruits by PC, which was 28.3. Considering the useful area per experimental plot of 5.6 $\mathrm{m}^{2}$, there was obtained NF/useful area ratio of, approximately, 5.6 fruits $/ \mathrm{m}^{2}$,
4.2 fruits $/ \mathrm{m}^{2}$ and 5.6 fruits $/ \mathrm{m}^{2}$ for $\mathrm{PD}$, $\mathrm{PC}$ and $\mathrm{CM}$, respectively. These values correspond to the average number of fruits per hectare, approximately 67,000 fruits/ha, 51,000 fruits/ha and 67,000 fruits/ha, respectively, for PD, PC and CM. The values obtained are superior to those found by Câmara et al., (2007) for melon cultivation in open field in the Northeastern semi-arid region. Those high average number of fruits are mainly due to plant density allowed by the cultivation system in a greenhouse and by the melon plant staking.

Technical recommendation for the cultivar used suggests that optimal productivity and fruit quality are obtained through cultivation between

Table 2. Productivity of yellow melon, cv. BRS Araguaia, cultivated in a greenhouse under different soil management systems in Brazilian Cerrado. Brasília, Embrapa Hortaliças, 2016.

\begin{tabular}{lccc}
\hline \multirow{2}{*}{$\begin{array}{l}\text { Management } \\
\text { system }\end{array}$} & $\begin{array}{c}\text { Commercial } \\
\text { productivity (t/ha) }\end{array}$ & $\begin{array}{c}\text { Fruit weight } \\
(\mathbf{g})\end{array}$ & $\begin{array}{c}\text { Marketable fruits } \\
\mathbf{( 1 , 0 0 0 / h a )}\end{array}$ \\
\cline { 2 - 4 } & \multicolumn{3}{c}{ First cycle } \\
\hline PD & $61.5 \mathrm{a}$ & $920 \mathrm{a}$ & $56.0 \mathrm{a}$ \\
$\mathrm{PC}$ & $44.2 \mathrm{c}$ & $870 \mathrm{a}$ & $57.1 \mathrm{~b}$ \\
$\mathrm{CM}$ & $59.7 \mathrm{~b}$ & $890 \mathrm{a}$ & $55.7 \mathrm{a}$ \\
\hline $\mathrm{CV}(\%)$ & 15.98 & 6.71 & 8.75 \\
\hline & & Second cycle & $44.3 \mathrm{a}$ \\
\hline $\mathrm{PD}$ & $61.2 \mathrm{a}$ & $839 \mathrm{a}$ & $33.4 \mathrm{~b}$ \\
$\mathrm{PC}$ & $40.1 \mathrm{~b}$ & $870 \mathrm{a}$ & $42.5 \mathrm{a}$ \\
$\mathrm{CM}$ & $57.5 \mathrm{a}$ & $888 \mathrm{a}$ & 19.8 \\
\hline $\mathrm{CV}(\%)$ & 18.79 & 6.28 & \\
\hline
\end{tabular}

$\mathrm{PD}=$ No-tillage; $\mathrm{PC}=$ Conventional tillage; $\mathrm{CM}=$ Minimum tillage. Averages (columns) followed by the same letter do not differ by Scott-Knott test at $5 \%$.

Table 3. Quality of yellow melon cultivated in a greenhouse under different soil management systems in Brazilian Cerrado. Brasília, Embrapa Hortaliças, 2016.

\begin{tabular}{lcccc}
\hline \multirow{2}{*}{$\begin{array}{l}\text { Sultivation } \\
\text { system }\end{array}$} & $\begin{array}{c}\text { Total soluble } \\
\text { solids ( } \mathbf{0} \text { Brix) }\end{array}$ & $\begin{array}{c}\text { Pulp firmness } \\
(\mathbf{N})\end{array}$ & $\begin{array}{c}\text { Pulp thickness } \\
(\mathbf{c m})\end{array}$ & $\begin{array}{c}\text { Longitudinal } \\
\text { length }(\mathbf{c m})\end{array}$ \\
\cline { 2 - 5 } & \multicolumn{5}{c}{ First cycle } \\
\hline $\mathrm{PD}$ & $13.15 \mathrm{a}$ & $49.88 \mathrm{a}$ & $3.22 \mathrm{a}$ & $12.05 \mathrm{a}$ \\
$\mathrm{PC}$ & $12.83 \mathrm{a}$ & $50.83 \mathrm{a}$ & $3.11 \mathrm{a}$ & $11.52 \mathrm{a}$ \\
$\mathrm{CM}$ & $12.98 \mathrm{a}$ & $50.50 \mathrm{a}$ & $3.24 \mathrm{a}$ & $11.81 \mathrm{a}$ \\
\hline $\mathrm{CV}(\%)$ & 5.68 & 1.95 & 3.39 & 3.12 \\
\hline \multicolumn{5}{c}{ Second cycle } \\
\hline $\mathrm{PD}$ & $11.89 \mathrm{a}$ & $47.1 \mathrm{a}$ & $2.97 \mathrm{a}$ \\
$\mathrm{PC}$ & $12.66 \mathrm{a}$ & $45.2 \mathrm{a}$ & $3.06 \mathrm{a}$ & $14.09 \mathrm{a}$ \\
$\mathrm{CM}$ & $13.10 \mathrm{a}$ & $50.6 \mathrm{a}$ & $3.02 \mathrm{a}$ & $14.82 \mathrm{a}$ \\
\hline $\mathrm{CV}(\%)$ & 11.64 & 11.35 & 13.00 & 11.49 \\
\hline
\end{tabular}

$\mathrm{PD}=$ No-tillage $; \mathrm{PC}=$ Conventional tillage $\mathrm{CM}=$ Minimum tillage. Averages (columns) followed by the same letter do not differ by Scott-Knott test at $5 \%$. 
May and November (Oliveira et al., 2011), in the main producing regions, mainly due to the weather characteristics of the period, high temperature and low rainfall. In the present study, the cultivation was from October to January in the first cycle (rainy and hot conditions) and from August to November, in the second cycle (dry and warm). However, in the two cycles, productivity, average weight of fruit and average number of marketable fruits were similar, demonstrating a possible efficiency of cultivation in a greenhouse for maintaining stable production in the two periods of the year.

\section{Fruit quality}

Based in the analysis of variance at $5 \%$ significance level, there were no significant statistic differences in relation to all the variables used to measure the quality of melon, in the two crop seasons (Table 3). Similar results were found by Miranda et al. (2003) and Braga et al. (2010). Câmara et al. (2007) however, verified the influence of different kinds of mulches on pulp thickness and firmness, as well as soluble solid contents, contrasting with results obtained by the authors previously mentioned and in the present study. Questions on the influence of

Table 4. Pearson's correlation coefficients between fertility attributes of the soil prior to the cultivation and marketable fruit productivity and average number of marketable fruits. Brasília, Embrapa Hortaliças, 2016.

\begin{tabular}{|c|c|c|c|c|}
\hline \multirow{3}{*}{ Attributes } & \multicolumn{2}{|c|}{2013} & \multicolumn{2}{|c|}{2014} \\
\hline & PFC & NMF & PFC & NMF \\
\hline & \multicolumn{4}{|c|}{$\mathrm{CM}$} \\
\hline $\mathrm{pH}$ & $-0.01^{\mathrm{ns}}$ & $0.05^{\mathrm{ns}}$ & $0.06^{\mathrm{ns}}$ & $0.32^{\mathrm{ns}}$ \\
\hline $\mathrm{P}$ & $0.48^{\mathrm{ns}}$ & $0.59^{\text {ns }}$ & $0.43^{\mathrm{ns}}$ & $0.17^{\mathrm{ns}}$ \\
\hline K & $-0.09^{\mathrm{ns}}$ & $0.08^{\mathrm{ns}}$ & $0.54^{\mathrm{ns}}$ & $-0.04^{\mathrm{ns}}$ \\
\hline $\mathrm{Ca}$ & $-0.24^{\mathrm{ns}}$ & $-0.24^{\mathrm{ns}}$ & $0.25^{\mathrm{ns}}$ & $0.52^{\mathrm{ns}}$ \\
\hline $\mathrm{Mg}$ & $-0.43^{\mathrm{ns}}$ & $-0.23^{\mathrm{ns}}$ & $-0.08^{\mathrm{ns}}$ & $0.42^{\mathrm{ns}}$ \\
\hline $\mathrm{H}+\mathrm{Al}$ & $0.06^{\mathrm{ns}}$ & $0.05^{\mathrm{ns}}$ & $-0.05^{\text {ns }}$ & $-0.20^{\mathrm{ns}}$ \\
\hline MOS & $-0.32^{\mathrm{ns}}$ & $-0.54^{\mathrm{ns}}$ & $0.75^{\mathrm{ns}}$ & $0.40^{\mathrm{ns}}$ \\
\hline \multirow[t]{2}{*}{ CTC } & $-0.26^{\mathrm{ns}}$ & $-0.22^{\mathrm{ns}}$ & $0.32^{\mathrm{ns}}$ & $0.57^{\mathrm{ns}}$ \\
\hline & \multicolumn{4}{|c|}{ PC } \\
\hline $\mathrm{pH}$ & $-0.70^{\mathrm{ns}}$ & $-0.64^{\mathrm{ns}}$ & $-0.24^{\mathrm{ns}}$ & $0.11^{\mathrm{ns}}$ \\
\hline $\mathrm{P}$ & $-0.04^{\mathrm{ns}}$ & $-0.06^{\mathrm{ns}}$ & $-0.12^{\mathrm{ns}}$ & $-0.22^{\mathrm{ns}}$ \\
\hline K & $0.27^{\mathrm{ns}}$ & $0.12^{\mathrm{ns}}$ & $0.56^{\mathrm{ns}}$ & $0.69^{\text {ns }}$ \\
\hline $\mathrm{Ca}$ & $-0.20^{\mathrm{ns}}$ & $-0.18^{\mathrm{ns}}$ & $0.73^{\text {ns }}$ & $0.89 *$ \\
\hline $\mathrm{Mg}$ & $-0.30^{\text {ns }}$ & $-0.22^{\mathrm{ns}}$ & $0.55^{\mathrm{ns}}$ & $0.77^{\mathrm{ns}}$ \\
\hline $\mathrm{H}+\mathrm{Al}$ & $0.81^{\mathrm{ns}}$ & $0.74^{\mathrm{ns}}$ & $0.26^{\mathrm{ns}}$ & $-0.06^{\mathrm{ns}}$ \\
\hline MOS & $0.06^{\mathrm{ns}}$ & $0.14^{\mathrm{ns}}$ & $0.55^{\mathrm{ns}}$ & $0.47^{\mathrm{ns}}$ \\
\hline \multirow[t]{2}{*}{ CTC } & $-0.12^{\mathrm{ns}}$ & $-0.12^{\mathrm{ns}}$ & $0.82 *$ & $0.92 *$ \\
\hline & \multicolumn{4}{|c|}{ PD } \\
\hline $\mathrm{pH}$ & $-0.78^{\mathrm{ns}}$ & $-0.64^{\mathrm{ns}}$ & $-0.62^{\text {ns }}$ & $-0.18^{\mathrm{ns}}$ \\
\hline $\mathrm{P}$ & $0.51^{\mathrm{ns}}$ & $-0.05^{\mathrm{ns}}$ & $0.07^{\mathrm{ns}}$ & $-0.16^{\mathrm{ns}}$ \\
\hline K & $0.58^{\mathrm{ns}}$ & $0.05^{\mathrm{ns}}$ & $-0.23^{\text {ns }}$ & $0.06^{\mathrm{ns}}$ \\
\hline $\mathrm{Ca}$ & $-0.38^{\mathrm{ns}}$ & $-0.72^{\mathrm{ns}}$ & $0.40^{\mathrm{ns}}$ & $0.62^{\mathrm{ns}}$ \\
\hline $\mathrm{Mg}$ & $0.43^{\mathrm{ns}}$ & $-0.22^{\mathrm{ns}}$ & $-0.02^{\text {ns }}$ & $0.14^{\mathrm{ns}}$ \\
\hline $\mathrm{H}+\mathrm{Al}$ & $0.74^{\mathrm{ns}}$ & $0.49^{\text {ns }}$ & $0.53^{\mathrm{ns}}$ & $0.15^{\text {ns }}$ \\
\hline MOS & $0.34^{\mathrm{ns}}$ & $-0.23^{\mathrm{ns}}$ & $-0.05^{\text {ns }}$ & $0.45^{\text {ns }}$ \\
\hline CTC & $-0.09^{\text {ns }}$ & $-0.09^{\text {ns }}$ & $0.45^{\mathrm{ns}}$ & $0.48^{\mathrm{ns}}$ \\
\hline
\end{tabular}

mulch on qualitative characteristics of melon fruits, which should be evaluated, still remain. Such variables are known as genetic traits and, they may be more related to the melon hybrid used in the assay than to the soil management system (Araújo Neto et al., 2003; Terceiro Neto et al., 2013).

Soluble solid contents (Table 3) observed for the treatments in this study are similar to those obtained by Gualberto et al. (2001) for net melon cultivated in a protected environment in the State of São Paulo. These values are higher than those obtained by other authors (Araújo Neto et al., 2003; Miranda et al., 2003; Nunes et al., 2005; Câmara et al., 2007; Paiva et al., 2008; Braga et al., 2010), reproducing different production systems of yellow melon commonly used in the Northeastern semi-arid region.

Pulp firmness (Table 3) was higher than the ones found in studies of Nunes et al. (2005), Câmara et al. (2007) and, Paiva et al. (2008). High pulp firmness is a trait of the cultivar BRS Araguaia, when stored for 42 days at room temperature and refrigerated conditions, obtaining the same average values 41.2 $\mathrm{N}$ and $33.2 \mathrm{~N}$, respectively (Oliveira et al., 2011). Another justification for these higher values may be the period between fruit harvest and analysis to determine pulp firmness. In the present work, fruit analysis was carried out right after harvesting, and always on the same day. On the other hand, in the assay conducted by Nunes et al. (2004), pulp firmness evaluation was carried out after 20 days of cold storage. Studies carried out by Câmara et al. (2007) and Paiva et al. (2008), did not mention this time interval.

The average pulp thickness observed for melon fruits are in accordance with those found in other studies with hybrids of yellow melon cultivated in different planting systems (Paiva et al., 2008; Santos et al., 2011). Nunes et al. (2005) verified for edaphoclimatic conditions of the Northeastern semi-arid region and open field cultivation average pulp thickness of approximately 1 centimeter higher than values observed in the current study.

The average fruit longitudinal length 
and weight indicate the reduced fruit size, when compared to the results obtained by Paiva et al. (2008). Gualberto et al. (2001) obtained similar results to those of the present research, for net melon cultivated in the State of São Paulo, in a protected environment, using the productive system with tutoring of plants and spacing of $0.7 \mathrm{~m}$ among rows. These results reinforce the idea that the plant density may be responsible for the smaller size of the produced fruits.

Melon productivity and quality results of the current study were similar between the two cultivation cycles and compared to the results reported by Gualberto et al. (2001) for net melon, using similar productive systems and climatic conditions. Despite the small size of the produced fruits, they were differentiated by their traits, for example, by the high content of soluble solids. This may add value to the final product.

\section{Effects of soil management systems}

The use of PD increased significantly the productivity of marketable fruits in the first cycle and, with CM, in the second cultivation cycle (Table 2 ). Productivity levels in the two first systems were superior to PC and also to the national average in the two cultivation cycles. Also, the use of PD and CM led to the production of higher average number of marketable fruits when compared to PC. Thus, the joint use of cultivation in a protected environment and adoption of more conservation practices such as $\mathrm{PD}$ and $\mathrm{CM}$ potentiated the production of yellow melon under the evaluated edaphoclimatic conditions.

There were no significant correlations between fertility attributes of the soil measured prior to implement the experiment (Table 4), in the first cultivation cycle, and the results for PFC and NMF. In the second cultivation cycle, there were significant correlation coefficients only for PC and between: PFC and CTC; NMF and CTC and; NMF and $\mathrm{Ca}^{2+}$ contents. These results indicate the possibility of increasing these two productive components linked to the management system.

In conclusion, the use of PD and $\mathrm{CM}$ in a greenhouse resulted in higher productivity increasing the average number of produced fruits, when compared to PC.

\section{REFERENCES}

AGRIANUAL. 2013. Agrianual: Anuário da agricultura brasileira. São Paulo. 482p.

ARAÚJO, AP; NEGREIROS, MZ; LEITÃO, MMVBR; PEDROSA, JF; BEZERRANETO, F; ESPÍNOLA SOBRINHO, J; FERREIRA, RLF; NOGUEIRA, ICC. 2003. Rendimento do melão amarelo cultivado em diferentes tipos de cobertura do solo e métodos de plantio. Horticultura Brasileira 21: 123-126.

ARAÚJO NETO, SEV; GURGEL，FL; PEDROSA, JF; FERREIRA, RLF; ARAÚJO, AP. 2003. Produtividade e qualidade de genótipos de melão-amarelo em quatro ambientes. Revista Brasileira de Fruticultura 25: 104-107.

ASSIS, RL; LANÇAS, KP. 2005. Avaliação dos atributos físicos de um Nitossolo Vermelho Distroférrico sob sistema de plantio direto, preparo convencional e mata nativa. Revista Brasileira de Ciência do Solo 29: 515-522.

ASSIS, RL; LANÇAS, KP. 2010. Agregação de um Nitossolo Vermelho Distroférrico sob sistemas de plantio direto, preparo convencional e mata nativa. Engenharia Agrícola 30: 58-66.

BRAGA, MB; RESENDE, GM; MOURA, MSB; DIAS, RCS; COSTA, ND; CALGARO, M; CORREIA, JS; SILVA, FZ. 2010. Produtividade e qualidade do melão submetido a diferentes tipos de cobertura do solo. Irriga 15: 422-430.

BRANDENBERGER, L; WIEDENFELD, B. 1997. Physical characteristics of mulches and their impact on crop response and profitability in muskmelon production. HortTechnology 7: 165-168.

CÂMARA，MJT; NEGREIROS, MZ; MEDEIROS, JF; BEZERRA NETO, F; BARROS, JÚNIOR, AP. 2007. Produção e qualidade de melão amarelo influenciado por coberturas do solo e lâminas de irrigação no período chuvoso. Ciência Rural 37: 58-63.

CARNEIRO, MAC; SOUZA, ED; REIS, EF; PEREIRA, HS; AZEVEDO, WR. 2008. Atributos físicos, químicos e biológicos de solo de cerrado sob diferentes sistemas de uso e manejo. Revista Brasileira de Ciência do Solo 33: 147-157.

FIGUEIREDO, CC; RESCK, DVS; GOMES, AC; FERREIRA, EAB; RAMOS, MLG. 2007. Carbono e nitrogênio da biomassa microbiana em resposta a diferentes sistemas de manejo de um latossolo vermelho no cerrado. Revista Brasileira de Ciência do Solo 31: 551-562.

FILGUEIRA, FAR. 2008. Novo manual de olericultura: agrotecnologia moderna na produção e comercialização de hortaliças. Viçosa: UFV. 421p.

FRIZZONE, JA; CARDOSO, SS; REZENDE, R. 2005. Produtividade e qualidade de frutos de meloeiro cultivado em ambiente protegido com aplicação de dióxido de carbono e de potássio via água de irrigação. Acta Scientiarum 27: 707-717.

GUALBERTO, R; RESENDE, FV; LOSASSO, PHL. 2001. Produtividade e qualidade do melão rendilhado em ambiente protegido em função do espaçamento e sistema de condução. Horticultura Brasileira 19: 240-243.

HAMADA, E; GHINI, R; MARENGO, JA; THOMAZ,MC. 2012. Projeções de mudanças climáticas para o Brasil no final do século XXI. In: GHINI, R.; HAMADA, E; BERTIOL, $\mathrm{W}$ (eds). Impactos das mudanças climáticas sobre as doenças de importantes culturas do Brasil. Jaguariúna: Embrapa Meio Ambiente. p. 43-74.

IPCC. 2013. Summary for Policymakers. 2014. Disponível em <http://www. climatechange2013.org/images/report/ WG1AR5_SPM_FINAL.pdf> Acessado em 20 de março de 2014.

LOURENÇÃO, WAP; JÚNIOR, SS; NEVES, JF; DIAS, LDE; NODARI, IDE. 2013. Produção de melão amarelo sob coberturas e cultivo convencional em Cáceres-MT. In: CONGRESSO DE INICIAÇÃO CIENTÍFICA, 5. Anais...Cáceres: UNEMAT. Disponível em http://siec.unemat.br/anais/ conic/impressao-resumo_expandido. php? fxev $=$ MA $==$ HYPERLINK $=$ I. Acessado em 20 de março de 2014.

MIRANDA, NO; MEDEIROS, JF; NASCIMENTO, IB; ALVES, LP. 2003. Produtividade e qualidade de frutos de melão em resposta à cobertura do solo com plástico preto e ao preparo do solo. Horticultura Brasileira 21: 490-493.

MORAIS, ERC; MAIA, CE; NEGREIROS, MZ. ARAÚJO JÚNIOR, BB. 2010. Crescimento e produtividade do meloeiro Torreon influenciado pela cobertura do solo. Acta Scientiarum Agronomy 32: 301-308.

MORAIS, ERC.; NEGREIROS, MZ; ARAÚJO JÚNIOR, BB; MEDEIROS, JF. 2008. Crescimento e produtividade do meloeiro Goldex influenciado pela cobertura do solo. Scientia Agraria 9: 129-137.

NETO, MS; PICCOLO, MC; VEZKE, SP; FEIGL, BJ; CERRI, CC. 2010. Mineralização e desnitrificação do nitrogênio no solo sob sistema de plantio direto. Bragantia 4: 923936.

NUNES, GHS; SANTOS JÚNIOR, JJ; ANDRADE, FV; BEZERRA NETO, F; ALMEIDA, AHB; MEDEIROS, DC. 2004. Aspectos produtivos de qualidade de híbridos de melão cultivado no agropolo de MossoróAssu. Horticultura Brasileira 22:744-747.

NUNES, GHS; SANTOS JÚNIOR, JJ; ANDRADE, FV; BEZERRA NETO, F; MENEZES, JB; PEREIRA, EWL. 2005. Desempenho de híbridos de melão do grupo inodorus em Mossoró. Horticultura Brasileira 23: 90-93.

OLIVEIRA, VR; BOITEUX, LS; COSTA, ND; BUSO, JA; ARAGÃO, FAZ; CARVALHO, ADF; COELHO, M; BUSO, GSC; ASSIS, JS; DIAS, RCS; PAIVA, WO; REIS, A; DUSI, NA; LOPES, CA; MORETTI, CL; GUEDES, IMR; PINHEIRO, JB; MATTOS, LM; LIMA, 
MF; SOUZA, RB; MELO, WF. 2011. BRS Araguaia: cultivar híbrida de melão amarelo. Horticultura Brasileira 29: S3219-S3226.

PAIVA, WO; MARQUES, GV; MESQUITA, JBR; DANTAS, RS; FREITAS, FWA. 2008. Qualidade e conservação de frutos de melão Amarelo em dois pontos de colheita. Revista Ciência Agronômica 39: 70-76.
SANTOS, MF; COSTA, CC; OLIVEIRA, EM; BARBOSA, JWS. 2011. Avaliação de genótipos de melão amarelo em Paulista, PB. Tecnologia e Ciência Agropecuária 5: 1-6.

SILVA, MCC; MEDEIROS, JF; NEGREIROS, MZ; SOUZA, VF. 2005. Produtividade de frutos de meloeiro sob diferentes níveis de salinidade de água de irrigação com e sem cobertura do solo. Horticultura Brasileira 23: 202-205.

TERCEIRO NETO, CPC; GHEYI, HR; MEDEIROS, JF; DIAS, NS; CAMPOS, MS. 2013. Produtividade e qualidade de melão sob manejo com água de salinidade crescente. Pesquisa Agropecuária Tropical 43: 354-362. 